\title{
Alexander von Humboldt and British artists: the Oriental taste
}

\author{
Elisa Garrido \\ Instituto de Historia CCHS-CSIC, Madrid, Spain \\ e-mail: elisa.garrido@cchs.csic.es
}

Submitted: 28 July 2013; Accepted: 9 September 2013

\begin{abstract}
Humboldtian landscape is the best result of a close relationship between artists and scientists in the context of the Enlightenment. Many artists inspired Humboldt to develop his concept of landscape as the best way of representing Nature, but some British artists in particular were a strong reference for him. Thomas Daniell and William Hodges had travelled to Asia creating a particular imagery, which inspired the desire to travel and the feeling of the exotic taste in Humboldt. Around Humboldt, mainly two types of artists have been studied: on the one hand, painter travellers who received direct instructions from Humboldt after his experience in America, and on the other, artists who started their trips by themselves after reading his works. However, this paper is focused on the links between Humboldt and these British painters of the Orient, whom he met on a European tour with Georg Forster, before making his trip to America.
\end{abstract}

KEYWORDS: Alexander von Humboldt; Georg Forster; Travel Literature; Thomas Daniell; William Hodges; Landscape Painting; Orientalism; East India Company

Citation / Cómo citar este artículo: Garrido, Elisa (2013) "Alexander von Humboldt and British artists: the Oriental taste". Culture \& History Digital Journal 2(2): e026. doi: http://dx.doi.org/10.3989/chdj.2013.026

RESUMEN: Alexander von Humboldt y los artistas británicos: el gusto oriental.- El paisaje teorizado por Humboldt es el resultado de una estrecha relación entre artistas y científicos, en el contexto de la Ilustración. Muchos artistas inspiraron a Humboldt a desarrollar su concepto del paisaje como la mejor forma de representar la naturaleza pero particularmente, algunos artistas británicos supusieron una fuerte referencia para él. Principalmente, alrededor de Humboldt se han estudiado dos tipos de artistas: por una parte, los pintores viajeros que recibieron instrucciones directas de Humboldt tras su experiencia en América y por otra, los artistas que iniciaron sus viajes por iniciativa propia tras haber leído los sus trabajos. Sin embargo, este texto se centra en las relaciones entre Humboldt y los pintores británicos de Oriente, a quienes él conoció en su viaje europeo junto a Georg Forster, antes de realizar su viaje americano.

PALABRAS CLAVE: Alexander von Humboldt; Georg Forster; Literatura de viajes; Thomas Daniell; William Hodges; Pintura de paisaje; Orientalismo; Compañía Británica de las Indias Orientales

Copyright: (C) 2013 CSIC. This is an open-access article distributed under the terms of the Creative Commons Attribution-Non Commercial (by-nc) Spain 3.0 License.

\section{ART AND SCIENCE IN HUMBOLDTIAN LANDSCAPE}

Alexander von Humboldt (1769-1859) was a German-born geographer, explorer and naturalist whose quantitative work on botanical geography laid the foundation for the field of biogeography. His travelogues and other works, kept him in the public eye until the end of his life. From 1799 to 1804 he travelled throughout the Americas showing a new way of depicting the tropical nature, offering Europe a picture of the New World that had never 
been seen before. The naturalist believed in science which needed art to feel the nature, in order to fully understand what was being observed, in that way he showed the American landscapes to Europe. Therefore, Alexander von Humboldt appeared as the synthesizer of the strictest analytical view common to natural scientists and the artistic view of the painter, whose soul is touched by the sublime spectacle of nature.

Although Humboldt gained much from his contact with Spanish scientists such as, among others, Mutis and Malaspina (Puig-Samper, 2012), who had a wide and rich experience of New World Nature, he was considered to be the re-discoverer of America and, in fact, it is stated that he reinvented South America as nature itself, since "he never tired of admiring its majesty and noble vigour" (Gerbi, 2010: 321). Humboldt wanted to depict American nature in its fullness as he had experienced it, offering it to a civilized Europe in its wholly dramatic and extraordinary sense, which even exceeded the Linnaean categorization; a view capable of overwhelming human understanding (Pratt, 2010: 211-267). Even though he is mainly a scientist, he felt himself to be a romantic artist facing the lush American landscapes, where his narrative became particularly dramatic by the feelings produced by being face to face with the immensity of nature; these views moved Humboldt's soul. His understanding of nature as something which raised the human spirit, but which could also be scientifically registered. In some points of his work, Humboldt struggled between his scientific and his romantic spirit, confessing to be afraid of quantifying and classifying Nature, afraid of it becoming something graspable, so losing all of its evocative magic:

\footnotetext{
It is almost with reluctance that I am about to speak of a sentiment, which appears to arise from narrowminded views or from a certain weak and morbid sentimentality, I allude to the fear entertained by some persons, that nature may by degrees lose a portion of the charm and magic of her power, as we learn more and more how to unveil her secrets, comprehend the mechanism of the movements of the heavenly bodies, and estimated numerically the intensity of natural forces (Humboldt, 1848: 18).
}

In the Eighteenth-Century, a modern concept of the world replaced the vision of a harmonious cosmos with a new sense of order based on the scientific method. In that sense, the voyages of discovery marked a turning point from the idea of a contained Nature to that of an uncontrollable cosmos. Also, the new discoveries had created a new way of living and of looking at Nature. When, in 1735, Linnaeus published Systema Naturae naturalist iconography reached a level of detail never seen before, being expressed in botanical and zoological drawings, which became tools of knowledge. At the same time, it was a historic moment for the History of Art, when aesthetic categories such as the sublime and picturesque began to be constantly discussed. Many travellers were circulating around the globe, recording everything they saw. Consequently we can notice three ways of looking and representing nature: the political, the scientific and the artistic view; which are all closely related, as showed by Bernard Smith's work (1979 \& 1992). In her work Ojos Imperiales [Imperial Eyes], Mary Louise Pratt (2010) analyzes two types of aspirations prevailing in the scientific project of the Enlightenment, when the scientific interests of the French, British and Spanish were vying to launch scientific expeditions in their colonies. She observes a clear distinction between the [interested] pursuit of wealth and the [disinterested] pursuit of knowledge motivated by a competition between nations that was, after all, the driving force of European Expansion. The political view is rather strategic and it could be represented by maps, a visual tool for controlling lands; the scientific view could be visually materialized in the herbariums, however it could be different in speech but not in intentions inasmuch as Natural History was not unselfish (Pratt, 2010). The Enlightenment Project consisted of the systematization of knowledge to enclose the entire surface of the Earth; moreover, the system of Nature as a descriptive paradigm in itself meant not only the possession of resources but a benign way of a global domination. The artistic view could be represented by independent artist travellers who went around the world by themselves. It would be necessary to differentiate between those painters enjoying the patronage of the Spanish imperial state (Bleichmar, 2012) and others employed by naturalists like those of Mutis's workshops, from these painters who wanted to experience an artistic tour.

On many scientific expeditions, like those of Cook in the Pacific, Nature began to be emancipated from art and became a model for art itself, and the new exotic nature especially demanded new criteria of judgment (Kwa, 2005). While scientists travelled to collect new species in America, a lot of artists were travelling around looking for new exotic tastes, especially to the Orient, which was very much in demand by the European art market. Mildred Archer, in her study of the British artists Thomas and William Daniell, Early Views of India (1980) tells us how British painters were looking for the sublime, the experience of travel, which provided them with new cultures and tastes, above all, new ways of feeling and depicting the world around them. At least, the Enlightenment created a new picture of the world with a strong alliance between art and science (Stafford, 1984). In this context Humboldt can be assumed to be one of the first independent travellers, by which his new way of looking at nature can be understood as the result of the whole spirit of 
his time. Humboldt's achievement was to merge the most rigorous study of geography with the feeling that produced in man the internal forces of Nature. Humboldt explained that this combination of ways of looking needed more than a strict study of the rules, to understand the immensity of the cosmos in his soul, and this feeling could be only depicted with the art of landscape.

As the concept Humboldtian science (Jardine, Secord \& Spary, 1996; Dettelbach, 1996) is generally accepted to understand the extensive scientific work of Alexander von Humboldt, the Humboldtian landscape should be equally assumed by Art Historians. Many artists fostered the taste of the Humboldtian landscape and they rendered scenes described and mapped by Humboldt, following the methodology that he pioneered and making his landscape theories the main subject of their careers. Humboldt thought that painting had a great potential for science because it was able to depict accurate details of the visible as well as of the invisible, this was what Humboldt called an overall impression of landscape and what might be the most valuable of his new visual thinking (Pimentel 2004; Godlewska, 1999). Humboldt proposed a Tableau de la Nature [Picture of Nature], where all phenomena of nature could be summarized in a whole view, from the geographical to the human. Nowadays Humboldt's discourse can be placed not only in the scientific category, to which it certainly belongs, but also in an aesthetic discourse. In fact, he really felt great admiration for painting because of its wide capacity to report information beyond the words, as he said: "Notwithstanding all the richness and adaptability of our language, the attempt to designate in words, that which, in fact, appertains only to the imitative art of painter, it is always fraught with difficulty." (Humboldt, 1850: 223) For him, landscape was much more than a genre painting; it was the perfect way of presenting a set of interrelated forces in an "overall impression" which, at the same time, could also be dissected in each single detail. In this regard, Humboldt was one of the early pioneers in the modern sense of the term landscape, considering it as an entity embracing relationships of nature, society and culture as a concrete totality (Gómez Mendoza \& Sanz Herraiz, 2010).

In his extensive travels, Alexander von Humboldt became the first to conceptualize a natural landscape and feeling the Nature in a whole sense, looking at vegetation and environment with a painterly gaze. With the practice of travelling as the development of his writing, this traveller makes both a global science of nature, and not surprisingly he sometimes had internal dilemmas over the strictly scientific language and the expression that emerges from the deepest human feelings. Publications after his trip, were the result of a reflection after his empirical experience, which showed the interesting relationship between the personal experience of travelling and the scientific analysis, thus, Humboldt was the first in "describing the American mountain panorama as an aesthetic space" (Ette, 2008: 86). This artistic representation of Latin America under the influence of Alexander von Humboldt has been worked on by several scholars (Lubowski, 2009; Baron, 2005; Diener, 1999 \& 2007; Löschner, 1976). Even though Humboldt's interest in landscape painting was present mainly in his great last work Cosmos (1849), he had already outlined a theory about that in Essai sur la Géographie des Plantes (1805), but he would deal with it especially in his work Ansichten der Natur (1808) and later in Vues des Cordillères et monumens des peuples indigènes de l'Amérique (1810). In the last one he included large-format illustrations, carefully chosen by him and with the collaboration of many artists based in Rome.

\section{HUMBOLDT'S GRAND TOUR: FIRST APPROACH TO ORIENTAL LANDSCAPE}

During his long life Humboldt was mainly connected with three European countries: Germany, France and Russia; nevertheless, he had many relationships with several distinguished citizens of Great Britain. He visited London on several occasions and there he met many important members of the scientific community, such as Georg Forster, Warren Hastings and Joseph Banks. Georg Forster (1754-1794), German naturalist and travel writer, had accompanied Captain Cook on some trips, including his second expedition to the Pacific, which William Hodges had also participated in. Warren Hastings (1732-1818) was the first governor of British India and he sponsored the work of most of the artistic journeys there. Finally Joseph Banks (1743-1820), Master of the Botanical Science and President of the Royal Society. Clearly Humboldt knew how to move in the social circles of the cities he visited and establish relationships with the most relevant people. The contacts with some of these notable figures in British culture would greatly influence the development of his work.

In 1789, Alexander von Humboldt had entered the University of Göttingen. This school was the most modern and progressive in Germany, located in the electorate of Hanover, whose leaders had close links with England, therefore the lessons being taught had much of the "British common sense" (HagenHein, 1987: 20). Humboldt made some excursions with young students and scientists and of particular importance was the trip to Mainz, with the Dutch botanist Steven Jan van Geuns (1767-1795), where he spent eight days in the house of Georg Forster, a visit which allowed him to consolidate a friendship and a deep admiration for him. Forster proposed a trip to the Netherlands, England and France to him which triggered his passion for exploration from this 
moment onwards. Undoubtedly, Forster's personality greatly impressed him; he had sailed the South Seas with Captain James Cook and was an ardent supporter of the Revolution. Only fifteen years older, he had fully explored almost the whole world.

In March 1790, they departed on a ship to Düsseldorf and from there, through Brabant and Flanders, to England. True to this spirit which also would accompany him in his later trips, they saw all the places which could be visited such as mines, caves and gardens, as well as being able to interact with various personalities. They also had a remarkable encounter with British painting in the rooms of the Royal Academy.

Forster's influence on the young Humboldt was very important and his admiration for him was evident in the dedication of his first work Mineralogische Beobachtungen über einige Basalte am Rhein (1790), after their trip which was the turning point. Humboldt's diary of this journey had been thought to be lost but it was found some years ago (Kölbel, Sauerwein, Sauerwein, Kölbel \& Buckow, 2008). Moreover we also have the one written by Forster (1893).

That was the moment when Humboldt started to feel the desire to travel and discover new worlds. Shortly thereafter, two painters travelled to India in search of the oriental tastes much demanded by the art markets of the European bourgeoisie. William Hodges had travelled on Cook's second voyage and he was the first professional landscape painter to visit India, working for the East India Company and the Governor-General, Warren Hastings. He published a series of lavish prints entitled Select Views in India (1785-88) and an account of his Travels in India (1793). Thomas Daniell is better known for his paintings and topographical prints of Indian landscapes, based on sketches that he and his nephew William made on their travels. Daniell found it difficult to establish himself as a landscape painter in Britain, so in 1784 he gained permission from the East India Company to travel to Calcutta as an engraver, with William Daniell as his assistant. They published six volumes of aquatints entitled Oriental Scenery (1795-1815) and each volume contained twenty-four aquatints of Indian scenes. Daniell was aware that William Hodges had published his Select Views of India and was eager to ensure that his series of prints exceeded those of Hodges in terms of accuracy and content.

It is known that Alexander von Humboldt was in England about five times. The first was the aforementioned trip in 1790. Later, in 1814, Alexander von Humboldt and his brother Wilhelm stayed with the Prussian King Frederick William III in London. In 1817, Arago and Humboldt had another meeting in London to visit his brother the Prussian ambassador. In 1827, he travelled again to London through Calais and Dover. And finally, in 1842, Alexander von Humboldt went to England because of the baptism of the future King Edward VII, with King Frederick William IV of Prussia (Kölbel, Sauerwein, Sauerwein, Kölbel \& Buckow, 2008). Some of his correspondence is evidence also that he was in constant contact with England, after the return from America, because of his passion for the Oriental world and his constant desire to undertake a new expedition to Asia. A desire never fulfilled due to the rejection by the British crown.

The invitation to Humboldt and his brother Wilhelm to accompany the King of Prussia to London in June 1814 provided an opportunity to meet the Directors of the East India Company there and propose another scientific expedition, this time in Asia. As Humboldt had then written to Napoleon: "I will undertake an expedition to the sources of the Ganges and inside Asia" and to another correspondent, in 1812, "The aim of my Asiatic journey is the high mountain chain that stretches from the source of the Indus to the sources of the Ganges ... I would like to spend a year in Benares ..." (Théodoridès, 1966). Humboldt contacted the office of the East India Company several times, even with the support and protection of the King of Prussia for his Indian project. But unfortunately all this pressure was to no avail.

\section{VUES DES CORDILLÈRES: VIEWS OF EXOTIC NATURE}

Among the reproductions that were generated on Humboldt's journeys, undoubtedly Vues des Cordillères holds a really special place as one of the most spectacular works of the Prussian scientist. This great American picture book, conceived initially as an Atlas Pittoresque, consists of more than sixty illustrations and narrative fragments. However, this is not a work of images with texts, nor a narrative supplemented by illustrations, but rather both parts are enriched by each other forming the most aesthetic work of Alexander von Humboldt, in the pure style of a picturesque voyage. In the prologue of Vues, Humboldt quotes the British artist Thomas Daniell, leaving no doubt of his knowledge of the work of this academic painter:

Plusieurs paysages on été coloriés, parce que, dan ce genre de gravure, les neiges se détachent beaucoup mieux sur le fond du ciel, et que l'imitation des peintures mexicaines rendoit déjà indispensable le mélange de Planches coloriées et des Planches tirées en noir. On a senti combien il est difficile de donner aux premières cette vigueur de ton que nous admirons dans les Scènes Orientales de Mr. Daniel. (Humboldt, 1810: v)

Although he mentions Daniel [with one "l"], he makes a reference to his published work Oriental Scenery and it is certain that he was aware of the 
impact this work had been in England, as it was mentioned in a previous study of the Spanish edition of the Vues (Puig-Samper \& Rebok, 2010).

It is clear that Humboldt also knew William Hodges. In his last work, Cosmos, he told specifically about his stay in London which meant the turning point in developing their work. He affirms that it was at the home of Warren Hastings, the British politician and colonial administrator, where he could see the pictures of Hodges depicting the shores of River Ganges, which inspired his desire to come upon Tropical America:

If I might be permitted to instance my own experience, and recall to mind the source from whence sprang my early and fixed desire to visit the land of the tropics, I should name George Forster's Delineations of the South Sea Islands, the pictures of Hodges, which represented the shores of the Ganges, and which I first saw at the house of Warren Hastings, in London ... (Humboldt, 1849: 372)

Later, he talked again about William Hodges as a source of inspiration for other landscape painters of the Tropics, like Rugendas, Hildebrant or Bellermann, painters who created landscapes following the Humboldtian science after his travel to America:

\footnotetext{
These examples of a delineation of the physiognomy of natural scenery were not followed by many artist of merit before Cook's second voyage of circumnavigation. What Hodges did for the western islands of the Pacific, and my distinguished countryman, Ferdinand Bauer, for New Holland and Van Diemen's Land, has been since done, in more recent times, on a far grander scale, and in a masterly manner, by Moritz Rugendas, Count Clarac, Ferdinand Bellermann, and Edward Hildebrandt; for the tropical vegetation of America (Humboldt, 1849: 451).
}

Therefore, Hodge's and the Daniells' work could represent an important precedent in the visual representations developed by the Humboldtian landscape. These influences have not been sufficiently studied, nevertheless it is easy to find some parallels, or perhaps a direct influence, in the way that William Hodges and the Daniells looked to the Orient and how Humboldt looked to the Tropics.

While Hodges was a painter of the sublime, the Daniells composed their Indian landscapes to render the places they saw in India as literally and as accurately as possible. The American landscape defended by Humboldt was, indeed, the symbiosis between those two ways of understanding the art of painting: study and feeling. Oriental Scenery by Thomas Daniell, was publicly praised many times for its scientific precision; James Rennell, considered to be "the father of Indian Geography" talk about the work of Thomas Daniell in his most important work Memoir of a Map of Hindoostan (Rennell, 1783: 369):

Some geographical information concerning the upper part of the course of the Ganges, and its principal branches, appears at the foot of a very characteristic and beautiful sketch drawn by Mr. Daniel (...) as far as they go exhibit that firm attachment to truth and honesty of discrimination which I have observed in all of the works of this ingenious artist.

Likewise, when the engravings of the Daniells began to be known across London society, the Monthly Magazine admitted Daniell's scientific usefulness even for Natural History in an article (Almeida \& Gilpin, 2006: 191):

\begin{abstract}
The execution of these drawings is indeed masterly; there is every reason to confide in the fidelity of the representations and the effect produced by this rich and splendid display of Oriental Scenery is truly striking. Everything is drawn with the most astonishing accuracy. The animals, trees and plants are studies for the naturalists.
\end{abstract}

Daniell's work contributed greatly to creating the image of British India as a rich land of romantic glory. In addition, as Humboldt would do with Latin America, they contributed to diffusing the Indian culture, showing landscapes where human action was an active part of nature, integrating architecture, culture and life. As we have noticed before, Humboldt created his Vues thinking in picturesque scenes, a term that referred to the pictorial representation of scenes of Nature. The term picturesque had emerged strongly in the Eighteenth Century, occurring as a result of several philosophical, political and artistic ideas, very close to the new sensibility of British Romanticism. The picturesque was introduced by William Gilpin in his work Three Essays on Picturesque (1792) and strongly discussed and theorized by English Nineteenth-Century aesthetic scholars (Price, 1796; Payne Knight, 1805; and Repton, 1806). It was closely linked to the boundaries of art and nature (Hipple, 1957) and to the experience of Le Grand Tour, which Humboldt did in the company of Georg Forster. Picturesque was a term frequently used by Humboldt which connected him directly with the aesthetics of the English landscape painters who he probably met on the European tour. Among Humboldt's written works, Vues was a singular masterpiece in his production composed by images and related text, the same structure which Hodges and Daniell had chosen for their works of India. These artists worked according to principles which would become an important part of Humboldtian thinking, like analysis and synthesis, the recognition of the individual elements of a 
landscape and the integration of them in a whole through the art of painting. However, both worked like artists but also in the progress of knowledge.

Humboldt's attraction to the exotic was a constant in his works and it had existed since his youth. In the first volume of his Voyage aux régions équinoxiales du Nouveau Continent, fait en 1799, 1800, 1801, 1802, 1803 y 1804 par Al. de Humboldt et A. Bonpland (1814-25), he has already talked about his failed plan to travel to Egypt:

Je me croyois très-près $\mathrm{du}$ moment où je m'embarquerois pour l'Égypte, quand les événemens politiques me firent abandonner un plan qui me promettoit tant de jouissances. La situation de l'Orient étoit telle, qu'un simple particulier ne pouvoit espérer de suivre des travaux qui, même dans des temps plus paisibles, exposent souvent le voyageur à la méfiance des gouvernemens (Humboldt, 1814: 42)

During the Napoleonic wars it was difficult to travel eastwards, so Humboldt turned west and was extraordinarily fortunate to secure a passport from King Charles IV of Spain to enter the Spanish American possessions. However, this failed trip to the Middle East could be assumed even as a stimulus (Lubrich, 2003); also as Columbus's speculative proposal was to reach the East Indies and ironically, a failed oriental expedition was the starting point for the second discoverer of America.

Until the late Eighteenth-Century, British society did not have a visual idea of what was India, which would be based on first-hand observations of the artists. The imagery that was clear from the illustrations made by professional engravers who had never in fact been in India, gave rise to all kinds of dreams and fantasies, which would be progressively transformed into images by the artists working in situ, but inevitably through a European thought filter. This was very similar to what had happened to the image of America (Duviols, 1986). In fact, in recent years, some scholars have been noticing how the traditional discourse of tropicalism can be compared with that of Said's Orientalism (1978), in some way both legitimized essential differences between cultures and natures (Driver \& Martins, 2005). Indeed, the picturesque voyages were without exception deliberate expeditions in search of the exotic as shown by William Hodges in his writings which were examples of a recreation in a constant search for the exotic taste. The artists looking to the Anglo-Indian were so fitting with events in European art circles that this was the main reason for both Daniell and Hodges selling more works in England than they had never sold in India (Dewey, 1982). The definition of new aesthetic categories such as the picturesque and the sublime were supposed to be the big reason for these artists to embark on expeditions to unusual places, and these definitions fit perfectly with the scenes the Orient offered them; after seeing their landscapes, Humboldt undoubtedly felt the desire to discover the exotic, as he said. Finally, Vues turns out to be a constant comparison of the exotic between Asia and Latin America.

\section{CONCLUSION}

Humboldt believed in the importance of travel as a first-hand observation of nature, but he also stressed the need to convey the feelings that nature produced in man. As a scientist, Humboldt understood that nature must to be represented as accurately as possible, and as romantic, he understood that landscape art reproduced the natural world through its reflection in man's soul, which allowed it to be understood as a whole. He appeared as the synthesis between strict analytical view common to the natural scientist and the artist's view in awe at the sight of Nature. For this reason, it would not be strange to think that he could have been inspired by artists at the time of preparing his Atlas Pittoresque. The most interesting thing, indeed, is unravelling the different views which gave rise to Humboldt's visual thinking. Moreover, the publications of artists like the Daniells and William Hodges could be considered also as singular masterpieces which broke the boundaries between arts and sciences. Besides those already referred to, Daniell contributed to the knowledge of India, some early studies are beginning to readdress the work of William Hodges to a new point of view, considering his contributions to ethnology, history of geographical exploration, Indian history and the development of empirical science (Quilley \& Bonefill, 2004). If we compare the plates, analyzing some iconographic elements, their great variety and their richness of information, it is easy to find similarities of composition, and those images could also be considered as "pictures of nature", as Humboldt would theorize a few years later.

Moreover, there is still much that might be said about Humboldt's relations with England and his first trips to Europe, a kind of Grand Tour that has not been deeply studied. In the England of the Eighteenth-century visited by Humboldt, the revolution of aesthetic theory favoured the artistic discovery of exotic worlds like India. This was the reason for artists to embark on expeditions to the East and probably Humboldt also felt the same, looking for the landscapes offered by the tropical regions. These pictures inspired Humboldt to travel and feel the exotic tastes, to the point of trying a new expedition to Asia, which alas, was finally thwarted.

\section{ACKNOWLEDGEMENTS}

Part of this paper is the result of the Project HAR2010-21333-C03-02, financed by the Ministry of Economy and Finance, Spain. 


\section{REFERENCES}

Almeida de, Hermione \& Gilpin, George H. (2006) Indian Renaissance: British Romantic Art and the Prospect of India. Ashgate Publishing, London.

Archer, M. (1980) Early Views of India: The Picturesque Journeys of Thomas and William Daniell 1786-1794. Thames and Hudson, London.

Baron, Frank (2005) "From Alexander von Humboldt to Frederic Edwin Church: Voyages of Scientific Exploration and Artistic Creativity". HiN (Humboldt im Netz), 6, 10. http://www.uni-potsdam.de/u/romanistik/humboldt/hin/ pdf/hin10/baron.pdf [Accessed 23/September/2013]

Bleichmar, Daniela (2012) Visible Empire: Botanical Expeditions and Visual Culture in the Hispanic Enlightenment. University of Chicago Press, Chicago \& London. http://dx.doi. org/10.7208/chicago/9780226058559.001.0001

Daniell, Thomas (1795-1808) Oriental Scenery. R.A., London.

Dettelbach, Michael (1996): "Humboldtian Science" in N. Jardine, J.A. Secord \& E.C. Spary (eds), Cultures of Natural History. Cambridge University Press, Cambridge.

Dewey, Clive (1982) Clive Dewey, "Figures in a Landscape: Anglo-Indian Art" in Modern Asian Studies, 16 (4): 683-697. http://dx.doi.org/10.1017/S0026749X00017303

Diener, Pablo (1999) "La estética clasicista de Humboldt aplicada al arte de viajeros". La ciencia del Nuevo Mundo, 2(3): 41-49.

Diener, Pablo (2007) "Lo pintoresco como categoría estética en el arte de viajeros: apuntes para la obra de Rugendas". HISTORIA, 40: II, 185-309.

Driver, Felix y Martins, Luciana (2005) Tropical Visions in an Age of Empire. University of Chicago Press, London. http:// dx.doi.org/10.7208/chicago/9780226164700.001.0001

Duviols, Jean-Paul (1986) L'Amérique espagnole vue et rêvée: les livres de voyages de Christophe Colomb à Bougainville. Editions Promodis, París.

Ette, Ottmar (2008) Literatura en movimiento: espacio y dinámica de una escritura transgresora de fronteras en Europa y América. CSIC, Madrid.

Forster, Georg (1893) Briefe und Tageblicher von seiner Reise am Niederrhein, in England und Frankreich. Fruhjahr, Halle.

Gerbi, Antonello (2010) The Dispute of the New World. Translated by Jeremy Moyle. University of Pittsburgh Press, Pittsburgh.

Gilpin, William (1792) Three essays: on picturesque beauty, on picturesque travel and on sketching landscape: to which is added a poem, on landscape painting. Printed for R. Blamire, London.

Godlewska, Anne Marie Claire (1999) "From Enlightenment Vision to Modern Science? Humboldt's Visual Thinking". In Geography and Enlightenment, edited by Livingstone, David N. \& Withers, Charles J., University of Chicago Press, Chicago, pp. 236-281

Gómez Mendoza, Josefina y Sanz Herraiz, Concepción (2010), "De la biogeografía al paisaje en Humboldt: Pisos de vegetación y paisajes andinos equinocciales". Población \& Sociedad, 17: 29-57.

Hagen-Hein, Wolfgang. et al. (1987) Alexander von Humboldt. La vida y la obra. Boehringer Sohn, Ingelheim am Rhein.

Hipple, Walter John (1957) The Beautiful The Sublime And The Picturesque In Eighteenth Century British Aesthetic Theory. Southern Illinois University Press, Carbondale.

Hodges, William (1793) Travels in India during the Years 1780, 1781, 1782 and 1783. Edwards, London.

Hodges, William (1785-88) Select Views In India, Drawn On The Spot, In The Years 1780, 1781, 1782 And 1783, And Executed In Aqua Tinta, R.A., London.

Humboldt, Alexander von (1790) Mineralogische Beobachtungen über einige Basalte am Rhein. Schulbuchhandlung, Braunschweig.

Humboldt, Alexander von (1805) Essai sur la géographie des plantes: accompagné d'un tableau physique des régions équinoxiales, fondé sur des mesures exécutées, depuis le dixième degré de latitude boréale jusqu'au dixième degré de latitude australe, pendant les années 1799, 1800, 1801, 1802 et 1803. Levrault, Schoell et cie, Paris.
Humboldt, Alexander von (1808) Ansichten der Natur. Cotta, Tübingen.

Humboldt, Alexander von (1810) Vues des cordillères, et monumens des peuples indigènes de l'Amérique. F. Schoell, Paris.

Humboldt, Alexander von and Bonpland, Aimé (1814-25) Voyage aux régions équinoxiales du Nouveau Continent, fait en 1799 , 1800, 1801, 1802, 1803 y 1804 par Al. de Humboldt et A. Bonpland; rédigé par Alexandre de Humboldt. F. Schoell, Paris.

Humboldt, Alexander von (1848) Cosmos: a sketch of a physical description of the universe. Translated From the German, by E.C. Otte. Volume I. H.G., Bohn, London.

Humboldt, Alexander von (1849) Cosmos: a sketch of a physical description of the universe. Translated From the German, by E.C. Otte. Volume II. H.G. Bohn, London.

Humboldt, Alexander von (1850): Views of nature: or contemplations on the sublime phenomena of creation. Translated from the German, by E.C. Otte. H.G. Bohn, London.

Humboldt, Alexander von (2010): Vistas de Las Cordilleras y Monumentos de Los Pueblos Indígenas de América. Edited by Puig-Samper, Miguel Ángel and Rebok Sandra. CSICDpto. de Publicaciones, Madrid.

Jardine, N, Secord, J.A \& Spary, Emma (1996) Cultures of Natural History. Cambridge University Press, Cambridge.

Kölbel Bernd, Sauerwein Martin, Sauerwein Katrin, Kölbel Steffen and Buckow Cathleen (2008) "Das Fragment des englischen Tagebuches von Alexander von Humboldt". HiN IX, 16 (2008): 10-23.

Kwa, Chunglin (2005) "Alexander von Humboldt's inventions of the Natural Landscape". The European Legacy, 10(2): 149-162. http://dx doi.org/10.1080/1084877052000330084

Löschner, Renate (1976) Lateinamerikanische Landschaftsdarstellungen der Maler aus dem Umkreis von Alexander von Humboldt. Unpublished thesis (PhD). Technische Universität Berlin, Berlin.

Lubowski, Alicia, (2009) The Picture of Nature: Alexander von Humboldt and the Tropical American Landscape. PhD dissertation, Institute of Fine Arts, New York University, New York.

Lubrich, Oliver (2003) “'Egipcios por doquier': Alejandro de Humboldt y su visión 'orientalista' de América”. Revista de Occidente, 260: 75-101.

Payne Knight, Richard (1805) An analytical inquiry into the principles of taste. Publisher T. Payne, London.

Pimentel, Juan (2004) "Cuadros y escrituras de la naturaleza". Asclepio, LVI-2: 7-24.

Pratt, Mary Louise (2010) Ojos Imperiales. Literatura de viajes y transculturación. México, FCE.

Price, Uvedale (1796) An essay on the Picturesque, as compared with the sublime and the beautiful. And on the use of studying pictures, for the purpose of improving real landscape. J. Robson, London.

Puig-Samper, M.A. (2012) "Illustrators of the New World. The Image in the Spanish Scientific Expeditions of the Enlightenment". Culture \& History Digital Journal 1(2): m102. doi: http://dx.doi.org/10.3989/chdj.2012.m102

Quilley, Geoffrey and Bonehill, John (editors), (2004) William Hodges 1744-1797: The Art of Exploration. Yale University Press, New Haven and London.

Repton, Humphry (1806) An enquiry into the changes of taste in landscape gardening: to which are added some observations on its theory and practice, including a defence of the art. J. Taylor, London. http://dx.doi.org/10.5962/bhl.title. 62780

Rennell, James (1783) Memoir of a Map of Hindoostan. Bulmer \& co., London.

Said, Edward (1978) Orientalism. Routledge \& Kegan Paul, London.

Smith, Bernard (1979) Art as Information: reflections on the art from Captain Cook's voyages. Sydney University Press, Sydney.

Smith, Bernard (1992) Imagining the Pacific in the Wake of the Cook Voyages. Yale University Press, New Haven.

Stafford, Barbara M. (1984) Voyage into substance: Art, science and nature and the illustrated travel account, 1760-1840. MIT Press, Cambridge Mass.

Théodoridès, Jean (1966) "Humboldt and England". The British Journal for the History of Science, 3 (1): 39-55. http:// dx.doi.org/10.1017/S0007087400000182 